\title{
THE SOCIO-ECOLOGICAL ANALYTICAL FRAMEWORK OF WATER SCARCITY IN RAFSANJAN TOWNSHIP, IRAN
}

\author{
S. MEHRYAR, R. SLIUZAS, A. SHARIFI \& M.F.A.M. VAN MAARSEVEEN \\ Department of Urban and Regional Planning and Geoinformation Management, Faculty of Geoinformation \\ Science and Earth Observation (ITC), University of Twente, Netherlands.
}

\begin{abstract}
Ground water scarcity is a main socio-ecological challenge in the Middle East. While ground water reserves seem vast, the impacts of over-exploitation and inadequate control over water consumption may threaten the sustainability of aquifers. The signs of aquifer depletion and its influence on water accessibility have become apparent in recent years. Using the case of Rafsanjan Township, Iran, this study aims to understand the socio-ecological factors and their inter-relationships in driving and exacerbating the water crisis situation, the ongoing policy responses and the possible consequences of current trends. The Drivers, Pressures, State, Impacts and Responses (DPSIR) framework, developed by the European Environmental Agency in 1999, is used to analyze the components of the socio-ecological system. Inputs are generated through a time series analysis of Landsat images, extracted spatial datasets, secondary literature and government reports.

This study illustrates the conflict between rapid economic development policies that have simulated the expansion of pistachio orchards on the one hand and sustainable water resource management on the other. Some responses based on a long-term socio-ecological resilient planning approach may provide a more sustainable perspective, but will require a substantial rethinking of current policies, improved water management practices, and additional research.

Keywords: DPSIR, socio-ecological system, water resource management, water scarcity.
\end{abstract}

\section{INTRODUCTION}

Rafsanjan Township, with a population of more than 280,000 people can be seen as a highly stressed socio-ecological system in which diminishing water resources are a decisive factor. This paper examines the socio-ecological variables of environmental changes due to the water crisis in Rafsanjan, and possible policy consequences.

The current water scarcity in Rafsanjan is derived from long term ecological and social challenges. Rafsanjan is located in one of the world's drought-prone areas, with an average annual precipitation of $137 \mathrm{~mm}$, equivalent to one-sixth of the world average precipitation [1]. Besides the periodic droughts and the effects of climate change, Rafsanjan, like many other parts of Iran, has been under the pressure of socio-economic shocks after the oil industry growth, white revolution and 1979 revolution of the country [2, 3]. Rapid population growth and economic instability after the revolution and the oil price change persuaded the Iranian government to implement economic development plans, supporting the industrial and agricultural sectors, to satisfy growing demand in the country and to make the country more self-sufficient [4-6]. However, the thirst for rapid economic development has largely ignored the negative impacts on natural resources by excessive concentrations of population and land uses throughout the potentially agricultural and industrial areas.

Rafsanjan as the main center of pistachio production and export in Iran has witnessed the accelerating expansion of agriculture derived by the economic development strategies. However, the long-term negative impacts of former development plans and their incompatibility with the available water resources are now being revealed. To illustrate the scale of the problem and the importance of a better integration between development policies and environmental 
resource management, this paper presents a detailed descriptive analysis of the changing socioecological system in Rafsanjan Township and particularly the increasing water scarcity.

The European Environment Agency's Driver-Pressure-State-Impact-Response (DPSIR) framework [7] is used to review the complex and causal relationships between key factors that contribute to water scarcity in Rafsanjan Township. Driving forces here are the socio-economic development and changes in society resultant changes in governing system and also peoples' lifestyles. Agro-economic development, oil-reliant economic development, population growth and change of water laws and legislations are among the main drivers examined in this paper. These driving forces lead to direct or indirect pressures that disturb the normal state of the environment. Agricultural expansion, unregulated groundwater exploitation and well construction, and change of lifestyle are described as the main pressures. These pressures in turn affect the state of the environment that is described by trends and the current situation. The state variables in this paper are declining groundwater levels, agricultural production reduction, land use change, and land subsidence. Changes in a state may generate social and ecological vulnerabilities which are defined as impacts. The impacts of water crisis in Rafsanjan are explained in three aspects of critical ecology of Rafsanjan Plain, land subsidence and vulnerable farmers' community. And finally, the responses are the actions taken by society or policy makers to improve the situation. The responses might be toward any part of the chain between driving forces and impact. The responses to combat the water crisis in Rafsanjan are described from water supply and demand control perspectives. Secondary data used in the analysis were collected from literature, government reports and official data and primary data were derived by using remote sensing image analysis (Landsat images of 28 years in time series of 1986, 1998, 2009 and 2014) as well as several informal interviews in October 2014 with key informants from the private sector, NGOs and the governmental water authority.

\section{CASE STUDY}

Rafsanjan Township consists of four districts, five urban areas, 14 dehestan (above village level) and 305 villages occupying $8288 \mathrm{~km}^{2}$ or $4.5 \%$ of the Kerman Province (Fig. 1). The city of Rafsanjan, located at $30^{\circ} 30 \mathrm{~N}$ and $55^{\circ} 40 \mathrm{E}$, with a population of 151,000 (Census

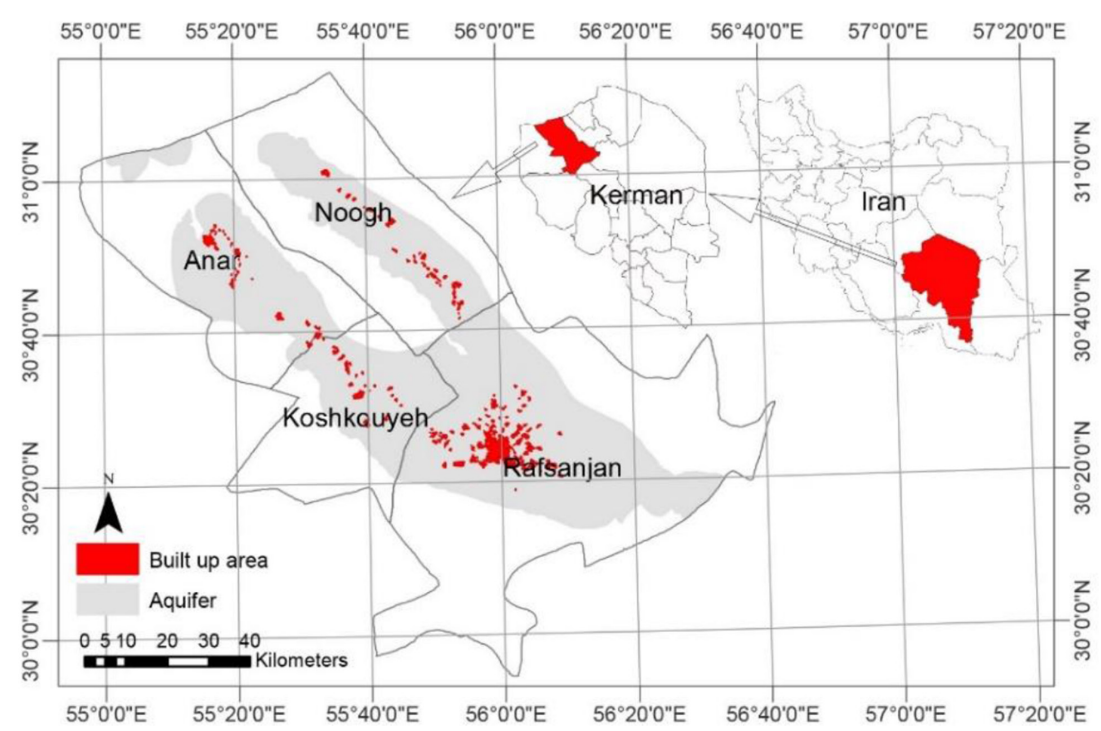

Figure 1: Location map of Rafsanjan Township in province and country, derived from Landsat 8. 
2011), is the township's largest city. Rafsanjan Township and Kerman Province are the main producers and exporters of pistachio in the world. Pistachio, termed the green gold of the country, is the main identity of this region. Almost $96 \%$ of agricultural lands in the township is allocated to the pistachio crop [8]. However, the growing concern with water scarcity is threatening the economic base of the region, its identity and its sustainability.

\section{DRIVERS}

\subsection{Agro-economic development planning}

Agriculture has always been prioritized by the Iranian government as the main engine of national economic development [9]. After the 1978 Revolution, the new Islamic Republic government used the term "Agriculture Jihad" (holy war), to satisfy the dramatically increasing food demand and also to improve the self-reliance of country [10]. Subsidizing of water and energy for the agricultural sector and importing higher technology of pumping wells were among the supportive actions of government to encourage agricultural expansion without considering the available natural resources of the country $[3,9]$.

Another decisive factor in agro-economic change in Iran was the rapid increase of oil revenue which is known as the "Dutch disease". This term is used when a country discovers a valuable natural resource deposit and begins large-scale exploitation of it and its revenues. As a result, the country's currency gains value [11], making the import of foreigner production more profitable. Over-dependency on a single export product makes the economy of a country highly vulnerable to that product's price fluctuation. In Iran, to overcome the economic shocks of oil price changes, the government adapted the dual exchange rate and put subsidies on water and energy for farmers [12]. Therefore, the large exchange rate difference in conjunction with cheap energy encouraged the farmers of Rafsanjan to import more pumping wells in order to expand pistachio production. The pump technology that was formerly unavailable and unaffordable became more beneficial and gradually replaced the traditional Qanat system for exploiting groundwater for irrigation [13]. Moreover, together with water and energy subsidies the high exchange rate for exporting pistachio made the pistachio production highly lucrative for the farmers in Rafsanjan [14].

\subsection{Population growth and urban expansion}

In the 20 years after the 1978 Islamic Revolution, due to the government's policy to stimulate Islamic population growth and to ban birth control, the country's population increased from 34 million to 63 million [15]. This "baby boom" contributed to a dramatic increase in water demand and so a reduced supply of renewable fresh water per capita [3]. Increased food demands and employment stimulated the government to further develop the agricultural sector.

The population data from the Statistical Centre of Iran [16] show that Rafsanjan Township experienced a high population growth after the Islamic Revolution too, with an annual growth rate of $2.5 \%$ between 1986 and 2006. This process is ongoing and based on 2009 census data it is estimated that by 2024 the urban population of Rafsanjan will have increased with $38 \%$ [17].

\subsection{Changes of water rights and their implementation}

Water laws and their enforcement have also played an important role in excessive agricultural water use in Rafsanjan. Traditionally, the farmers were used to invest in drilling wells for the operation and management of ground water. The utilization of water resources was governed 
by shari'a law (complex body of Islamic rules) and customs [18]. By the enactment of the Nationalization of Water Resources Act (NWRA) the underground water resources were considered as national property and their utilization and management were charged to the Ministry of Energy. In spite of many potential advantages of changing water governance from private to public goods, the water nationalization laws reduced the water users' participation. Since the rights of water users were not clearly defined by the NRWA, farmers perceived the new centralized water governance as an ownership loss and gradually lost their incentives to consider the aftereffects of their water over-extraction [14].

Another important water law that came into effect after the revolution was the Equitable Water Distribution Act (EWDA). As part of this law the definition of "prohibited plain" was identified based on judgments of two experts of the water authority [14]. Earlier, the prohibited plains were defined according to the water balance of aquifers, meaning the aquifers with a negative balance of ground water inflow and outflow would be called "prohibited plain" where well drilling and well discharge were forbidden. However, after EWDA many plains could get the discharge licence despite their negative aquifer imbalance based on these experts' judgements. In the rather chaotic situation after the revolution, populistic action of the policy makers and the corruption in governmental sectors exacerbated the over exploitation of groundwater in Rafsanjan. Apparently both small-holder famers and large landlords could highly benefit from this situation but only by depreciating critical communal ground water resources.

Moreover the misinterpretation of Islamic jurisprudence caused easier justification of excessive ground water exploitation. As an example, according to the Islamic water law the digger of a well, whether on his land or on unoccupied land, becomes the owner of the well water as soon as digging is completed [19]. After the revolution, many wells' discharges were licenced based on Islamic water laws and populistic actions of revolutionary politicians [14].

However, the vague water laws and legislations and their weak implementation and supervision, facilitated the violations, law breaking and water theft in Rafsanjan. According to the FAO Water description [20], for most local water users, water scarcity is not only about drought or wells drying up but above all it is about their fair and safe access to water. It is about how governments guarantee the equity, transparency and monitoring of law enforcement which has already been ignored through weak ground water governance in Rafsanjan.

\section{PRESSURES}

\subsection{Agricultural land expansion (pressure on ecology)}

Excessive agricultural area expansion is a direct pressure inflicted by the socio-economic drivers of development planning and population growth. To explore agricultural land expansion within the Rafsanjan Township, we prepared the NDVI images derived from Landsat satellite images over a 28 year period between 1998 and 2014 [13]. NDVI images are extensively used in determining water stress levels on vegetation and assessing drought impact [21-24]. Higher values of NDVI indicate healthier vegetation while unhealthy or sparse vegetation shows a lower value. These data show that the pistachio land area within the Rafsanjan Township has grown dramatically over recent decades. Around 35,000 ha were added to the vegetated area over this period which is almost one third of current planted area. Most agricultural expansion (52\%) occurred between 1998 and 2009, despite the drought that had started from 1999. Most of the agricultural expansion is located around Rafsanjan City in the south and the Noogh region in the east (Fig. 2). 

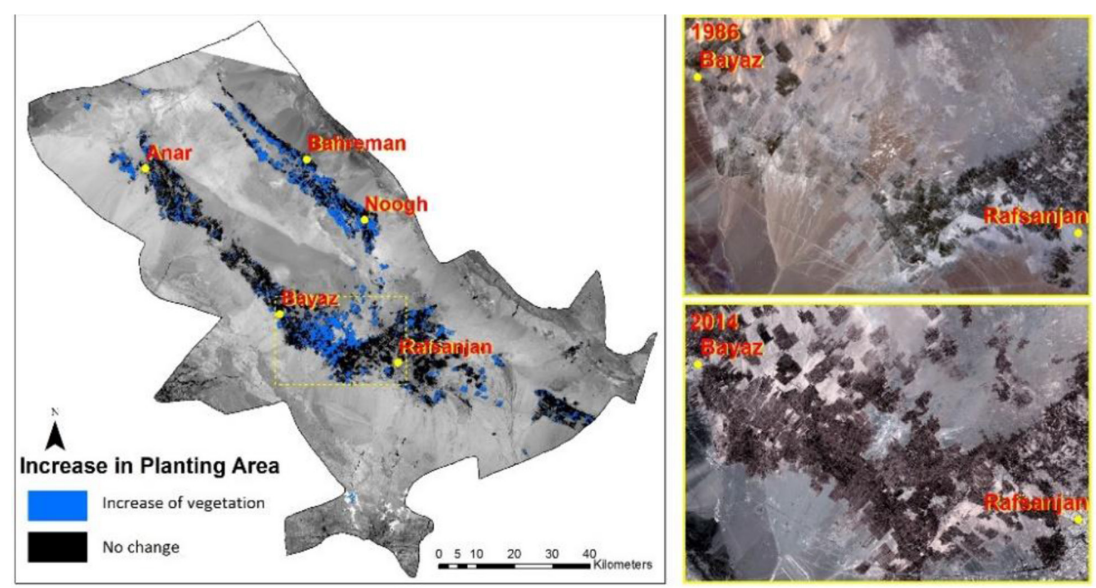

Figure 2: Vegetation increase in Rafsanjan Township between 1986 and 2014 [13].

\subsection{Unregulated groundwater exploitation and well construction (pressure on ecology)}

From 1970 till 2006, the number of wells in Rafsanjan township increased from 590 to 1392 [1]. Data indicate a striking increase of well drilling between 1971 and 1983 which is after the water nationalization, land reform and boom of oil trade in Iran. However, these data refer to legal wells while, according to local knowledge, the number of illegal wells drilled over the last 30 years even exceeds the number of legal wells.

The rapid increase of deep wells further reinforced the high pressure on groundwater exploitation creating a water imbalance in the aquifer. In 1974 Rafsanjan Plain, for the first time, was declared as "prohibited plain" due to a $20 \%$ overexploitation of groundwater [17] with an annual well discharge of 334 million $\mathrm{m}^{3}$. Nevertheless, the statistics of groundwater discharge in Rafsanjan plain (Fig. 3) show that water extraction reached 780 million $\mathrm{m}^{3}$ in 1993, more than twice the amount of 1974 . According to the most recent hydro-geological report [25], Rafsanjan's aquifer had 37\% overexploitation of the groundwater balance and $22 \%$ overexploitation of its permissible level. The government has set the permissible annual

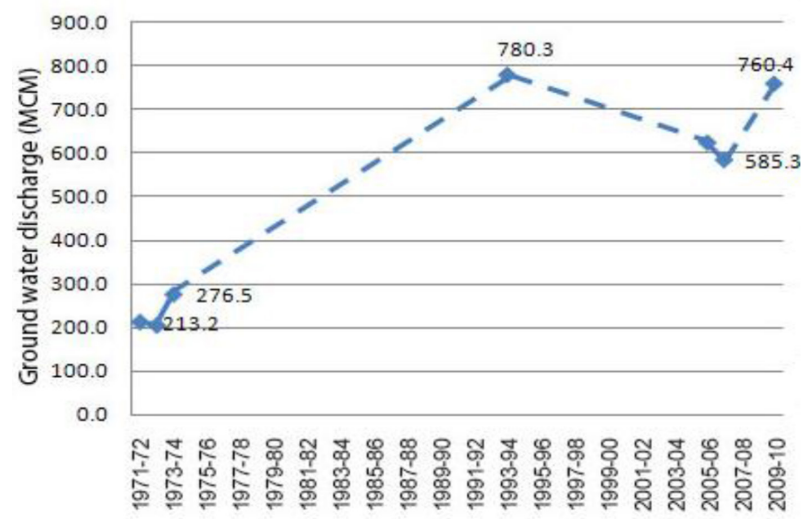

Figure 3: Total wells discharge in different sampling years [1]. 
extraction of 559 million $\mathrm{m}^{3}$ for this aquifer, while its actual annual extraction is recorded as 685 million $\mathrm{m}^{3}$ [8]. In 2009, the groundwater balance of Rafsanjan was -215 million $\mathrm{m}^{3}$ [17]. It is estimated that Rafsanjan has already used most of its groundwater resources and its aquifer has been classified as a "critical prohibited plain" by the government since 2006; implying that further well drilling in the region is not allowed and that groundwater withdrawal from licensed wells should be strictly controlled within specific limits set by the government.

\subsection{Change of life style (social pressure)}

Economic development has caused lifestyle changes accompanied with a growing water consumption culture. Although the urban water use accounts for only $3.5 \%$ of water consumption of Rafsanjan region, still the growth of population and water consumption per capita have created problems for a sustainable urban water balance in this region. The average domestic water consumption of Rafsanjan basin in 1994 was 155 litres per day per capita, while by 2007 this number increased to 175 litres per day per capita [17]. Currently the city of Rafsanjan's available urban water is $14 \%$ less than the actual consumption, with a shortfall of -2.2 million $\mathrm{m}^{3}$ [17]. It is one of the highest urban water shortages in the province and it is expected to worsen.

Moreover, the boom of precious pistachio production gave rise to a socio-economic pressure on the farmers' life styles. The high value of pistachio attracted people and economic activity to the centers of pistachio production, and thereby created a mono-cultural regional economy. Nowadays, in spite of the existence of copper mines and a cotton production tradition in this region, pistachio production has become the first economy and expertise of Rafsanjan. Currently, the majority of Rafsanjan's inhabitants are active in the production, trade and distribution of pistachios [16]. Therefore, the mono-cultural regional economy with its high dependency on pistachio production has made this region severely vulnerable to water scarcity.

\section{STATE}

\subsection{Decline of groundwater level (ecological state)}

The rapid rise in the number of pumped wells has led to large scale groundwater withdrawal and consequently depletion of the groundwater level in Rafsanjan. The hydrograph for the Rafsanjan plain in Fig. 4 shows a dramatic and continuous drop in the groundwater level, in particular after 1992. During the period 1983-2013, the depth of Rafsanjan plain aquifer has fallen by $20 \mathrm{~m}$. The sharp drop of the groundwater table $(0.75 \mathrm{~m}$ per year) demonstrates vividly the extent of over-use of non-renewable portion of groundwater.

\subsection{Land use change (vegetation area decrease)}

The spatial impact of drought and water scarcity in Rafsanjan can be observed by evaluating the vegetation changes in time series. Here again, the NDVI time series data detect the changes of vegetation caused by drought. The vegetation transformation of the Rafsanjan Township shows major changes in the 28 years between 1986 and 2014 (Fig. 5). Although there was widespread expansion of the planted area between 1986 and 2009, around $40 \%$ of 


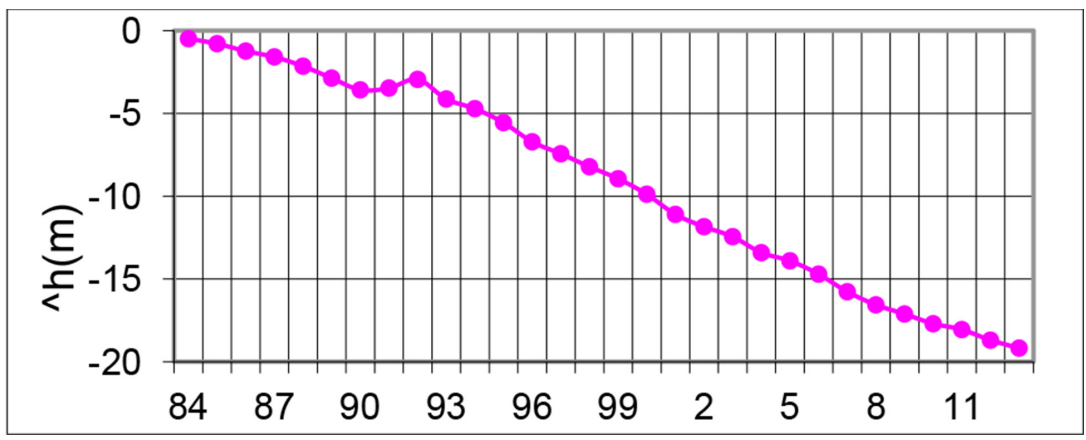

Figure 4: Ground water Hydrograph of Rafsanjan Plain from 1983 to 2013. Source: wrs.arm.ir.

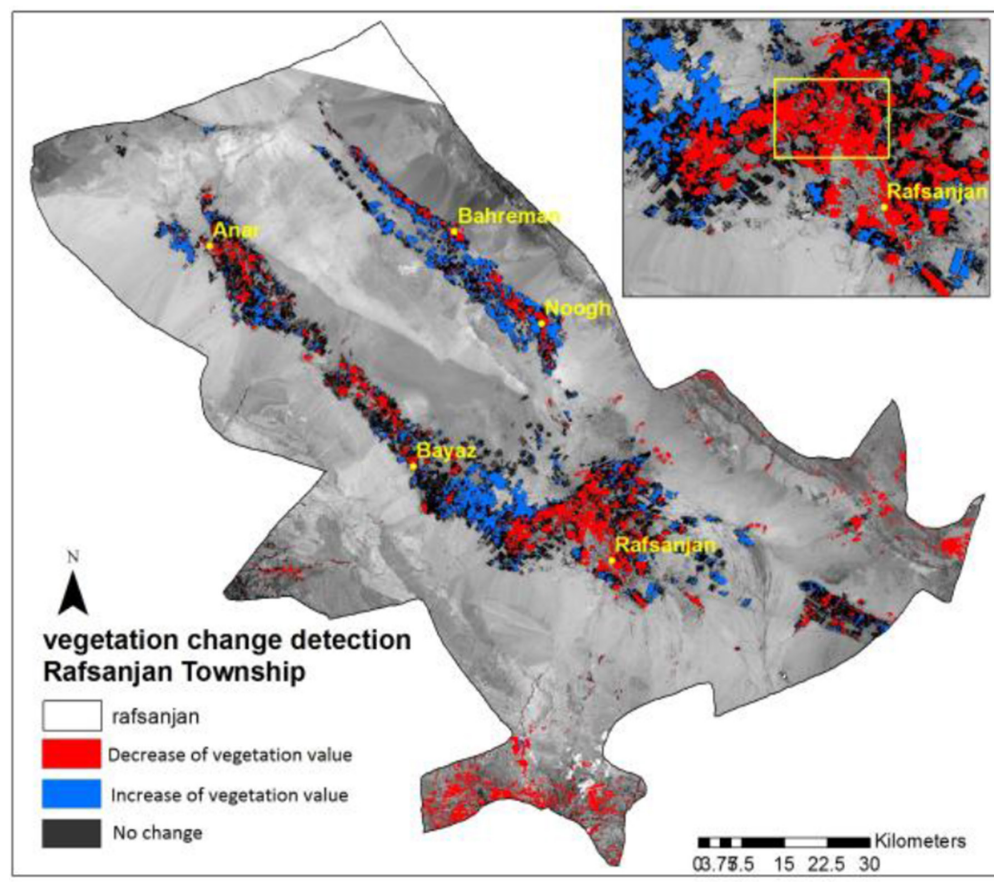

Figure 5: Vegetation change detection in Rafsanjan Township between 1986 and 2014 [13].

these planted areas lost their vegetation after 1998. The level of vegetation in around $30 \%$ of Rafsanjan planted area has decreased. Reduction of vegetation value is because of either change of land use around the four cities (specifically around Rafsanjan city), or drought related decrease of green vegetation. From 2009 to 2014, there has been only a decrease of vegetation value without any gain, unlike the previous period when both increases and decreases could be observed.

The change detection map shows that, most of the loss of vegetation occurred around Rafsanjan City. The previous studies of wells' depths and groundwater levels in Rafsanjan Township [13] indicate that the city of Rafsanjan has the lowest groundwater level in the 
aquifer. Most of the dry wells, with zero or very low discharge rate, are also concentrated around Rafsanjan City. While water accessibility is a critical issue throughout Rafsanjan Township, the impact of agricultural lands drying up seems different in various parts of this region. Some regions like north and east of Rafsanjan city and also the areas around Anar have witnessed more orchards drying up while the orchards between Rafsanjan and Bayaz and also the ones in the east of Township appear to be in better condition.

\subsection{Agricultural production and export decrease (economic state)}

Pistachios are Iran's biggest non-petroleum export item and, until 2007, the Islamic Republic was the world's top exporter of this crop. After saffron, pistachio is the most expensive agricultural crop in Iran.

In $2004,44 \%$ of world pistachio production and $60 \%$ of global exports were from Iran and $16.6 \%$ of the world production belongs to Rafsanjan. In the same year, USA was the second with a production and export share of $13 \%$ and $8.9 \%$ respectively [26]. While the production and export of pistachio have long been a matter of national pride, in 2012 and 2013 Iran has been overtaken as the top pistachio exporter by the United States of America [27]. In the year 2012, the pistachio production of Iran decreased from an annual average of 280 thousand to 150 thousand tons [28].

\section{IMPACTS}

\subsection{Critical ecology of Rafsanjan Plain (ecological impact)}

Severe ground water depletion in Rafsanjan has caused a malfunction of the wells. Most well throughputs are less than their licence limits which implies that the permissible discharge level of the Rafsanjan plain exceeds the availability of ground water. In some areas, the deepest wells with $400 \mathrm{~m}$ depth do not have access to ground water as mentioned in reports [1]. Moreover, the large scale ground water depletion resulted in increased salinity and a mix of fresh water with saline water. If the current trend of ground water depletion in Rafsanjan continues further conversion of the pistachio orchards into the desert can be expected. Desertification is the consequent impact in case of a business as usual scenario which is considered an irreversible situation socially and economically [17].

\subsection{Land subsidence (environmental impact)}

Excessive groundwater withdrawal in Rafsanjan has also led to new hydro-stress of land subsidence in the region [29-33]. The first acute land subsidence in Iran was observed in Rafsanjan since 1980. The 20 meter depletion in ground water level in the past 20 years is associated with a rate of subsidence of about 5-15 cm each year [29].

Land subsidence leads to fissures, increase of groundwater salinity, well damages (e.g. well casings rise above the surface) and cracks in buildings and roads [30]. The depth of measured fissures in Rafsanjan plain is up to six meters. Comparing InSAR-derived subsidence maps [31] and satellite images reveals that many of the agricultural and settlement areas are adjacent to dramatically shrinking ground water resources, where land subsidence is very probable. Most of land subsidence of 6-11 m, likewise, occurs in areas with wells of 145$380 \mathrm{~m}$ depth (Fig. 6). 

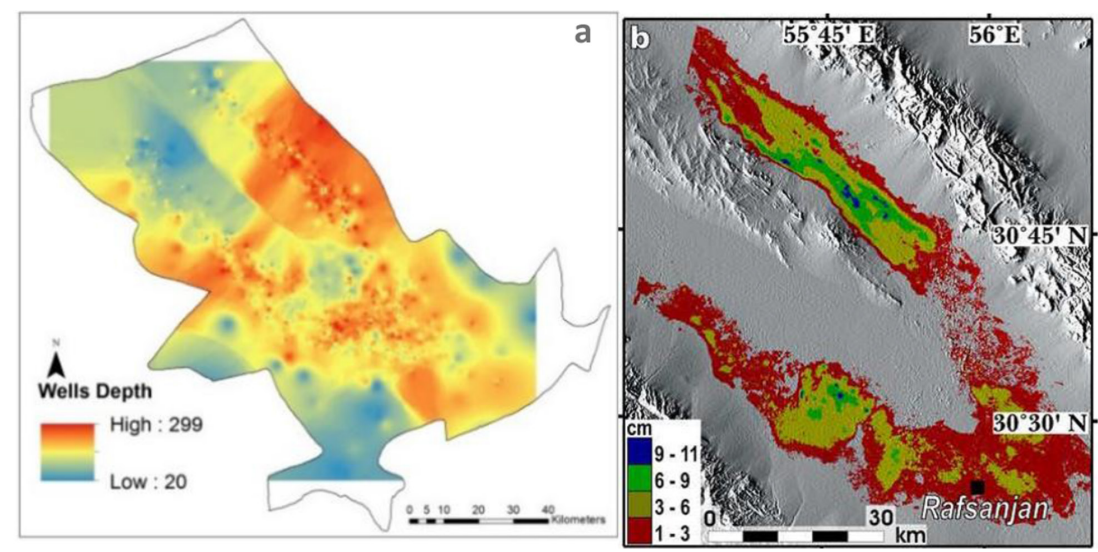

Figure 6: a. Wells Depth b. Ground displacement in areas of major land subsidence [31].

\subsection{Vulnerable farmers and economy of the region (socio-economic impact)}

The mono-culture economy of Rafsanjan has made the individual and regional economy of this township highly vulnerable to water scarcity. Water crises have inflicted costly adaptive activities of farmers like well deepening, expensive wells repairing, relocation of wells and purchasing of water from other wells. In some parts of Rafsanjan a new unofficial water market is emerging in which well water is traded amongst farmers at very expensive rates [1]. Adding to the diminishing production returns, farming activity in Rafsanjan is losing its economic profitability. Many farmers, especially the smallholders, have found their well water trade more beneficial than using water for agricultural production. Poverty and immigration are the social and economic impacts of water scarcity which is severely threatening Rafsanjan region [1].

\section{RESPONSES}

The above mentioned issues have led to a series of responses from government each of which is described below.

\subsection{Water supply management}

Large-scale water transfer projects are a supply-oriented management strategy prescribed by Iranian government in Rafsanjan and other basins confronting water scarcity. Currently the inter-basin water transfer projects from adjacent basins and also from the Persian Gulf are among the main responsive policies to protect agriculture of the region against acute water scarcity. Aside inter-basin conflicts over water and the high cost of water transfer projects, previous experiences have shown that these projects actually further stimulate demand and water shortages in the region [3]. Gohari et al. [33] identifies the water transfer projects as "a fix that backfire", in which side effects of further development and population growth result in higher water consumption, although they solve the problem temporarily. Therefore, supplying more water to the basin without considering the main driving forces of water shortage would only temporarily address the symptoms of the problem and not deal with the fundamental structural issues that should be addressed. 


\subsection{Water use control}

Groundwater pricing policies, well exploitation control and irrigation systems modification are among the main responses of the government to lessen the water demand in Rafsanjan. Due to the free access to groundwater the major costs in well water withdrawal are the energy costs to pump water which is reasonably cheap in Iran. Hence, there is no incentive for the farmers to reduce their agricultural water use or optimize their irrigation system. As an example only less than 5\% of the farmed area in Rafsanjan is under pressured irrigation [1], despite the efficiency gains it offers in reduced water consumption per ha.

Water pricing in Rafsanjan, and generally in Iran, has been suggested and is under development but not yet implemented. In recent years, the government has slightly raised energy prices [3] and has also begun to install smart groundwater monitoring devices [34] to control energy and water use. Nevertheless the effectiveness of these actions is not yet determined. To implement water and energy pricing, all the wells need to be registered and metered to record water use. To be effective and equitable, such measures need to be applied to all wells, both legal and illegal and the latter should also be either registered or shutdown.

Water and energy pricing is a general and responsive alternative to the driving force of weak groundwater management, and is aiming to provide incentives to save water consumption although it might also impose a certain extend of income losses to farmers [35] which may create public dissatisfaction and anger. Although raising water and energy costs may reduce wasting in many cases [36] the implementation of pricing mechanisms in China [37] and Spain [35] indicates that pricing water and energy alone and without serious efforts of water authorities and farmers to conserve water may even lead to the intensification of ground water over-exploitation. Varela-Ortega et al. [35] explains in the case of Spain that adaptation of water conservation strategies depends largely on agro-economic conditions, institutional and structural factors and financial situations of farmers more than water pricing. However, an effective water and energy pricing needs to be created first to ensure that equity and public goods issues are adequately covered [38] and second be intertwined with other interrelated strategies of water conservation.

\section{CONCLUSION}

The above historical analysis of water-related challenges in Rafsanjan reveals that the sevenyear drought considered and perceived by experts and local farmers, is not the only reason of water crisis in this region. A rapid but perhaps ill-conceived economic development accelerated by the weak groundwater governance has also had a most destructive impact on water resources. Iran's development plans for this region have mostly focused on economic development, self-sufficiency and self-reliance regardless the potential long-term environmental costs. Besides, the historical analysis of water management and governance in Rafsanjan reveals an increasing exclusion of water users from water governance. This has been driven by nationalization of water and later reinforced by inadequate laws and their unequal enforcement. Unlike the successful collective water management of the traditional Qanat system, the new "Water as a common pool" strategy has reduced peoples' participation and their role in water resource management which has led to the current groundwater over-exploitation.

While until very recently the government ignored the water crisis the current undesirable socio-ecological state of Rafsanjan shows the symptoms of the former approaches resulting in severe water scarcity. Studying the current state of groundwater balance indicates that Rafsanjan has already consumed most of its groundwater supplies. Due to the recent aquifer 
damage through subsidence, even if there would be a return to the past precipitation levels, the negative impact is irreversible. Satellite image analysis indicates that around 30 percent of the approximately 110,000 ha of pistachio lands in Rafsanjan has lost their vegetation. Moreover, local farmers' perceptions are that 50 percent of pistachio lands has lost its productivity.

Migration and desertification are the current and future impacts of the water crisis. Based on Iranian standards, Rafsanjan plain is earmarked as a "critical prohibited plain" meaning that stabilization of the aquifer's decline is the main goal. Moreover, local farmers are losing their incentive of keeping their pistachio lands. Massive transfers of pistachio lands to other plains is now occurring but this will likely export the water crisis to other regions too.

The inter-basin water transfer projects to pistachio farms is one government policy to respond to the water crisis and pistachio production problem. Aside the high costs of water transfer, this action needs careful consideration given the threat of inter basin conflicts as well as an expected further expansion of agricultural land in the region. The other water use control policies and actions from government like water pricing, wells control and irrigation system modification may not effectively respond to the problem if they are not considering effective participation of all stakeholders in water conservation practices. Moreover, a "one size fits all" solution to the water crisis is not possible. The spatial differences of water accessibility and quality, and their various socio-ecological impacts in Rafsanjan requires different but inter-related approaches in decision making.

The current analysis based on the DPSIR framework provides a holistic environmental overview over Rafsanjan's water crisis based on literature, government reports and quantitative analysis. However, further studies are required to explore the different stakeholder's perceptions and experiences of the water crisis in various parts of Rafsanjan and the impact of current policies on water use and accessibility. Future scenarios and decision making in Rafsanjan need to consider the involvement of both water users and policy makers at different levels and the socio-economic and ecological differences in various parts of Rafsanjan to enable a sustainable perspective for this very complex socio-ecological problem.

\section{REFERENCES}

[1] IWPRI, Sustainability of groundwater resources: case study of Rafsanjan plain. Iran Water Research Institute, 2014, [In Persian].

[2] Alizadeh, A. \& Keshavarz, A., Status of agricultural water use in Iran. Water Conservation, Reuse, and Recycling: Proceedings of an Iranian-American Workshop, 4, pp. 94-105, 2005.

[3] Madani, K., Water management in Iran: what is causing the looming crisis? Journal of Environmental Studies and Sciences, 4(4), pp. 315-328, 2014.

https://doi.org/10.1007/s13412-014-0182-z

[4] Gilanpour, O., Challenges of Iran's agriculture sector in accession Process to the WTO. Proceeding of Eighth European Trade Study Meeting, Vienna. Retrieved on http://www. etsg.org/ETSG2006/papers/Gilanpour.pdf, 2006.

[5] Khorami, A.R. \& Pierof, S., The role of agriculture in Iran's economic development. Research Journal of Applied Sciences, Engineering and Technology, 6(11), pp. 19281939, 2013.

[6] Metz, H.C., Iran: A Country Study, 4th edn., Federal Research Division, Library of Congress: Washington, DC, 1989. 
[7] Kristensen, P., The DPSIR framework. In workshop on a comprehensive/ detailed assessment of the vulnerability of water resources to environmental change in Africa using river basin approach, 2004.

[8] Jamab, Research on upgrading the comprehensive water plan. Energy ministry, water and wastewater macro-planning bureau, 2011, [In Persian].

[9] Shakoori, A., Planning and agricultural development in Iran. Critique: Critical Middle Eastern Studies, 15(3), pp. 265-282, 2006. https://doi.org/10.1080/10669920600997084

[10] Kalanatari, I., Failure of environmental authority in lagoons preservation, interviewed by Mozhgan Jamshidi. Etemad, 3170, 2014, [In Persian].

[11] Rudd, D., An Empirical Analysis of Dutch Disease: Developing and Developed Countries. Illinois Wesleyan University, Illinois, 1996.

[12] Farzanegan, M.R. \& Markwardt, G., The effects of oil price shocks on the Iranian economy. Energy Economics, 31(1), pp. 134-151, 2009.

https://doi.org/10.1016/j.eneco.2008.09.003

[13] Mehryar, S., Sliuzas, R., Sharifi, A. \& Maarseveen, M.V., The water crisis and socioecological development profile of Rafsanjan Township, Iran. WIT Transactions on Ecology and the Environment, 199, pp. 271-285, 2015.

https://doi.org/10.2495/RAV150231

[14] Agah, M. \& Hassani, M., Water rights in Iranian plateau: through socio-economic changes. Iran Water Research Institute, 2014, [In Persian].

[15] Roudi-Fahimi, F., Iran's family planning program: responding to a nation's needs. Population Reference Bureau, 2002.

[16] SCI. Statistical Centre of Iran, 2011, available at http://amar.org.ir/english/Census-2011

[17] RDPI, Integrated water resource management and planning in Kerman Province. Kerman Regional Water Authority, 2009, [In Persian].

[18] Alasti, S., Legislation on Use of Water in Agriculture: Iran. The library of congress website, legal reports, http://www.loc.gov/law/help/water-law/iran.php

[19] Caponera, D.A. \& Nanni, M., Principles of Water Law and Administration: National and International, Taylor \& Francis: London, 1, 1992.

[20] UN Water, Coping with water scarcity: challenge of the twenty-first century, In 2007 World Water Day, 2007.

[21] Peters, A.J., Walter-Shea, E.A., Ji, L., Vina, A., Hayes, M. \& Svoboda, M.D., Drought monitoring with NDVI-based standardized vegetation index. Photogrammetric Engineering and Remote Sensing, 68(1), pp. 71-75, 2002.

[22] Al-doski, J., Mansor, S. B. \& Shafri, H. Z. M., NDVI Differencing and Post-classification to Detect Vegetation Changes in Halabja City, Iraq. IOSR Journal of Applied Geology and Geophysics (IOSR-JAGG), 1(2), 2013.

[23] Gopinath, G., Ambili, G., Gregory, S.J. \& Anusha, C., Drought risk mapping of southwestern state in the Indian peninsula-A web based application. Journal of Environmental Management, 161, pp. 453-459, 2015.

https://doi.org/10.1016/j.jenvman.2014.12.040

[24] Himanshu, S., Singh, G. \& Kharola, N., Monitoring of drought using satellite data. International Research Journal of Earth Sciences, 3(1), pp. 66-72, 2015.

[25] Jamab, Research for adaptation planning in arid and semi-arid climate. National planning and management organization, water resource affairs bureau, 2004, [In Persain]. 
[26] Razavi, S., Pistachio production, Iran vs. the world. In IV International Symposium on Pistachios and Almonds, pp. 689-694, 2005.

[27] FAOSTAT, 2014. FAOSTAT online database http://faostat3.fao.org/compare/E

[28] R.P.P.C., Rafsanjan Pistachio Producers Cooperative, available at http://www.rppc.ir/, (30 August 2014).

[29] Dehghani, M., Rastegarfar, R., Ashrafi, A., Ghazipour, N. \& Khorramrooz, H.R., Interferometric SAR and geospatial techniques used for subsidence study in the Rafsanjan Plain. American Journal of Environmental Engineering, 4, pp. 32-40, 2014.

[30] Rahnama, M. \& Moafi, H., Investigation of land subsidence due to groundwater withdraw in Rafsanjan plain using GIS software. Arabian Journal of Geosciences, 2(3), pp. 241-246, 2009. https://doi.org/10.1007/s12517-009-0034-4

[31] Motagh, M., Walter, T.R., Sharifi, M.A., Fielding, E., Schenk, A., Anderssohn, J. \& Zschau, J., Land subsidence in Iran caused by widespread water reservoir overexploitation. Geophysical Research Letters, 35(16), L16403, 2008. https://doi.org/10.1029/2008GL033814

[32] Solaimani, K. \& Mortazavi, S.M., Investigation of the land subsidence and its consequences of large groundwater withdrawal in Rafsanjan, Iran. Pakistan Journal of Biological Sciences: PJBS, 11(2), pp. 265-269, 2008. https://doi.org/10.3923/pjbs.2008.265.269

[33] Gohari, A., Eslamian, S., Mirchi, A., Abedi-Koupaei, J., Bavani, A.M. \& Madani, K., Water transfer as a solution to water shortage: a fix that can backfire. Journal of Hydrology, 491, pp. 23-39, 2013.

https://doi.org/10.1016/j.jhydrol.2013.03.021

[34] Moazedi, A., Taravat, M., Jahromi, H. N., Madani, K., Rashedi, A. \& Rahimian, S., Energy-water meter: a novel solution for groundwater monitoring and management. In Proceedings of the World Environmental and Water Resources Congress, pp. 962-969, 2011. https://doi.org/10.1061/41173(414)99

[35] Varela-Ortega, C., Sumpsi, J. M., Garrido, A., Blanco, M. A. \& Iglesias, E., Water pricing policies, public decision making and farmers' response: implications for water policy. Agricultural Economics, 19(1-2), pp. 193-202, 1998.

https://doi.org/10.1016/S0169-5150(98)00048-6

[36] Dumol, M., The Manila water concession: a key government officials diary of the world's largest water privatization. The World Bank, 1, 2000.

https://doi.org/10.1596/0-8213-4711-X

[37] Yang, H., Zhang, X. \& ZehndeR, A.J., Water scarcity, pricing mechanism and institutional reform in northern China irrigated agriculture. Agricultural Water Management, 61(2), pp. 143-161, 2003. https://doi.org/10.1016/S0378-3774(02)00164-6

[38] Rogers, P., Silva, R.D. \& Bhatia, R., Water is an economic good: how to use prices to promote equity, efficiency, and sustainability. Water Policy, 4(1), pp. 1-17, 2002. https://doi.org/10.1016/S1366-7017(02)00004-1 